\title{
A Case Study on Customer Acquisiton and Retention on the Airline Service Industry
}

\author{
Dr. Lalita Shukla \\ (Ph.d) UGC NET Qualifier KRG College, Gwalior, India)
}

\begin{abstract}
This report provides an analysis on customer acquisition and retention on the airline industry. This research has been done because of the rapid increasing of airline service usage. In today's time where the competition is strict, knowing how to acquire and retained customers is very important. Hence, these project objectives are to find out what are the factors that affect customer's satisfaction and provide recommendations for better customers' acquisition, repetition and recommendation for airline service.

First of all, the airline industry background has been analyzed by Porter's five forces model. Based on the analysis, it shows that the power of suppliers and competition between existing firms in airline service industry is high. While, the threats of substitutes, power of buyer and threats of new entrants are relatively low. Moreover, in order to help airline companies to survive this strict competition, several important attributes have been provided to achieve the objectives. This includes Customer acquisition, Customer retention, Customer Satisfaction and loyalty, Service Recovery and Management and Training.

Next, this project use primary quantitative research method which is distributing survey and use several journal and books as a secondary research method to support the thesis. The sample size of the survey is 80 respondents. The data will be analyzed using XLD Data analyst. Based on the result, it shows several factors that affect customer's satisfaction which lead to acquisition, repetition and recommendations in purchasing airline service
\end{abstract}

Keywords: Customer Acquisition, Customer Acquisition, Customer Satisfaction, Airline.

Table of Contents

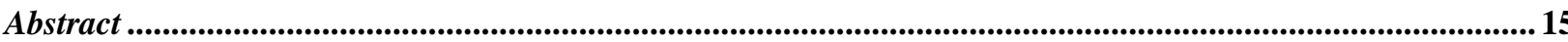

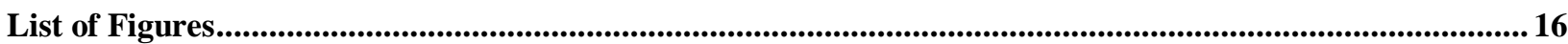

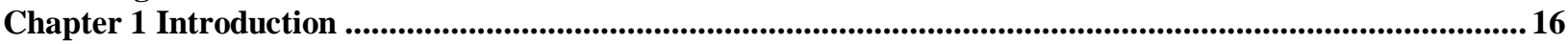

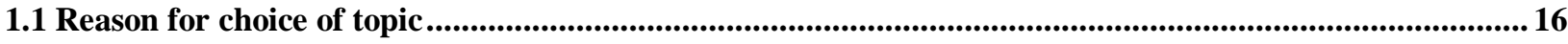

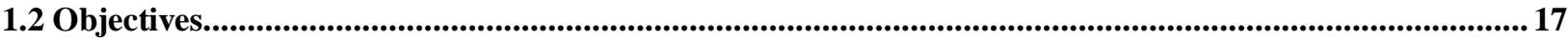

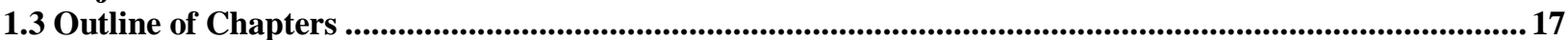

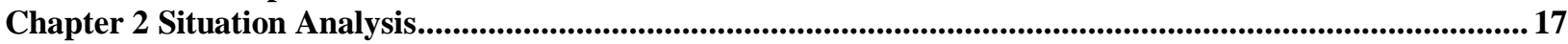

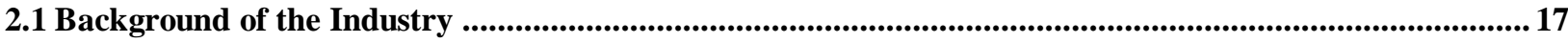

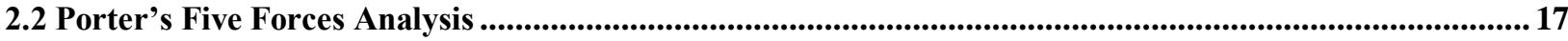

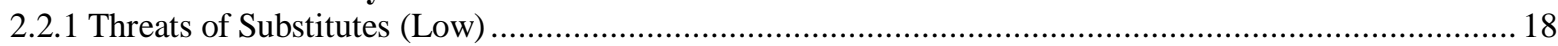

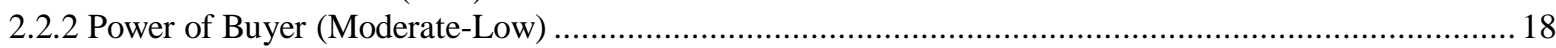

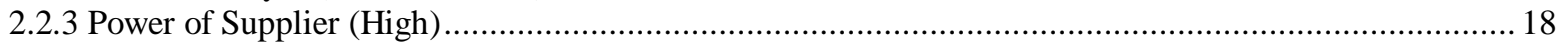

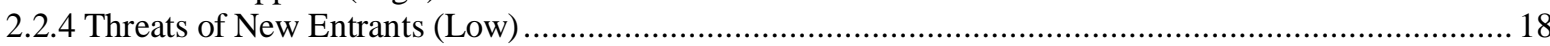

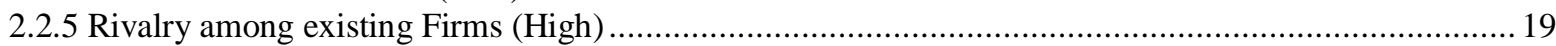

Chapter 3 Literature Review ................................................................................................................... 19

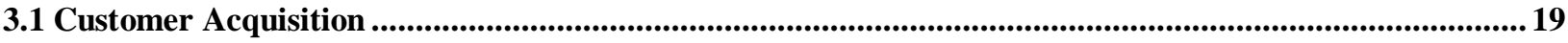

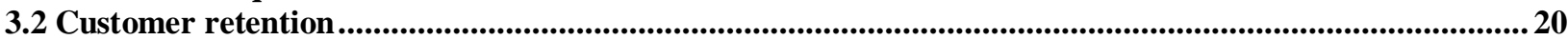

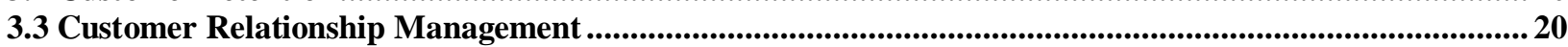

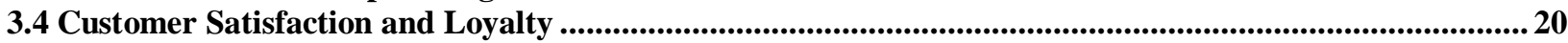

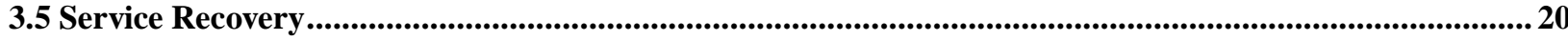

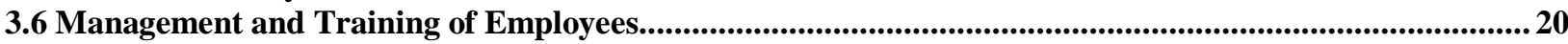

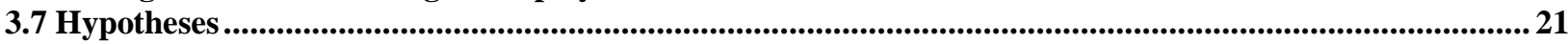

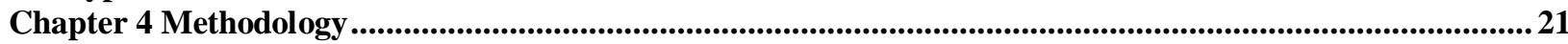

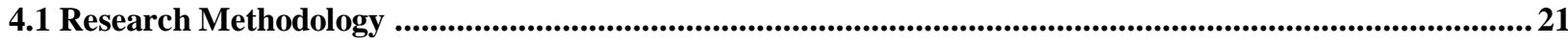

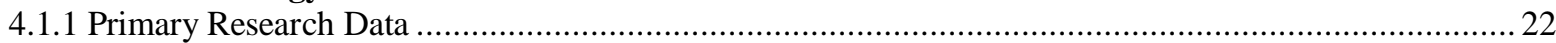

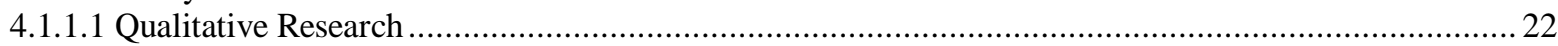

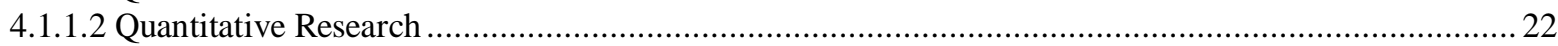

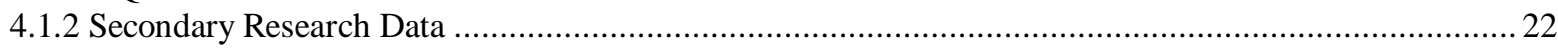

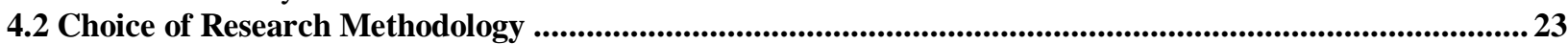

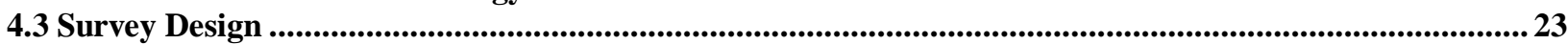


4.4 Pre-Test

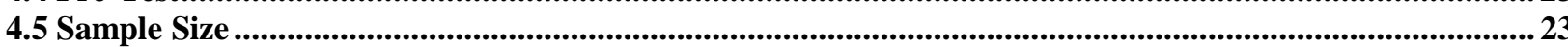

4.6 Evaluation of the Survey Results..........................................................................................................................23

4.7 Bias and Limitation of Research Process ............................................................................................................. 23

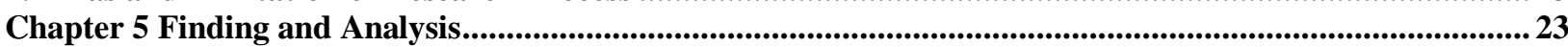

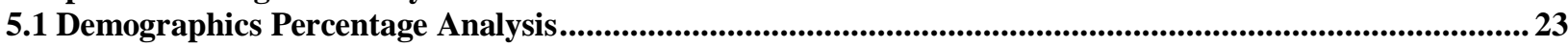

5.2 Cross Tabulation between does attractive price attract customers and what is your occupation................. 25

5.3 Cross Tabulation between the accessibility-or- place to gain service with the media or source to gain

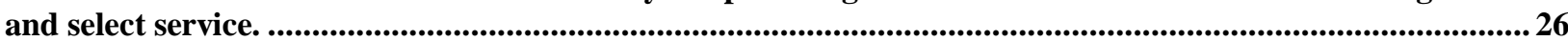

5.4 Cross Tabulation between the age group with the importance in keeping customers informed about the services through various media............................................................................................................................2 27

5.5 Correlation Test Analysis on Compensation/Service Recovery and Quality of service personnel................28

5.6 Multiple Regression Analysis to identify the factors that affecting customers in choosing airlines............. 28

Chapter 6 Conclusion and Recommendations .....................................................................................................30

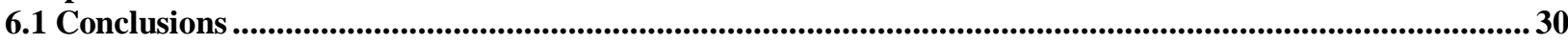

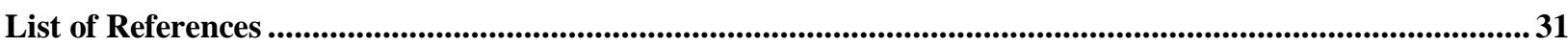

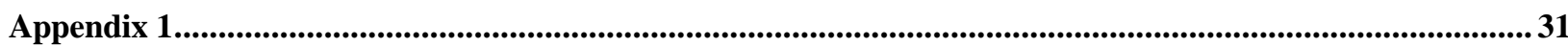

List of Figures

\begin{tabular}{|l|c|}
\hline Figure 2.1 & Page 12 \\
\hline \hline Figure 3.1 & Page 20 \\
\hline Figure 4.1 & Page 22 \\
\hline Figure 5.1 & Page 26 \\
\hline Figure 5.2 & Page 27 \\
\hline Figure 5.3 & Page 28 \\
\hline Figure 5.4 & Page 29 \\
\hline Figure 5.5 & Page 30 \\
\hline Figure 5.6 & Page 32 \\
\hline Figure 5.7 & Page 34 \\
\hline Figure 5.8 & Page 35 \\
\hline
\end{tabular}

\section{Introduction}

\subsection{Reason for choice of topic}

In today's time, due to increasing globalization in the world's economy and the rapid development in technology, the usage of airline service are increasing. This is supported by The International Air Transport Association (IATA) which has announced that "the global traffic result for March showing that total passenger demand rose $7.6 \%$ and freight demand climbed at $0.3 \%$ compared to same month last year" (IATA, 2012). Additionally, due to globalization now the nature of the market for airline service is wide. For example, now Singapore, Korea, Japan, Philippine and Indonesia can provide airline service to each other or other countries within their region due to globalization. Moreover, the function of airline service today has improved, as besides it allows people to go to other region, it also provide a goods delivery. These show that the market in airline industry has great opportunity to grasp.

Furthermore, by the appearance of budget airline service, the number of people that can travel has tremendously increased as budget airlines provide airline services at shoestring price. This incident affects the intensity of the competition in the market which highlights the need for company in this industry to be able acquire and retain their customers effectively in order to stay competitive in the market. In relation with acquiring and retaining, the need of excellent service personnel is fairly crucial as they are the one who directly interact with the customers (Palmer, 2011).

With the good opportunity in airline service industry, the author wants to study and analyze rigorously the Airline service industries in regards to how companies can best acquire and retain their customers in this fierce competition. This project will be focused more on the airline service in Singapore's region as the market for airlines is very wide. 


\subsection{Objectives}

This research aims to achieve the following objectives:

1. Evaluate the imperatives of Customers Acquisition and Retention

2. To identify what are the factors that affect customers in choosing/acquiring a particular Airline Service

3. To identify what are the factors that made customer satisfy; make repeat purchase and recommend a particular airline service

4. Lastly is to recommend strategies for company to efficiently and effectively acquire and retain customers for present and long term.

\subsection{Outline of Chapters}

Chapter one explains an introduction of the chosen topic, research of the academic objectives for this project, followed by an outline of chapters of this research.

Chapter two is the setting scenes which cover situation analysis that start with the background of the industry. In this chapter, porter five forces model (Porter, 1991) will be used to analyze the situation in this airline service industry.

Chapter three refers to the literature review which is the key theories that the author finds to be related and necessary to achieve the objectives of this project. These key theories are acquisition, important and determinant attributes, retention, and service recovery and customers satisfaction which will be discussed in details.

Chapter four assesses scope of the data and various methodologies that are being used to achieve the objectives, design of the questionnaire, sources of bias and limitation of research process. All these attributes will be discussed more comprehensive in this chapter.

Chapter five discusses the findings and analysis of the data gathered from the questionnaire by using the XLD data analysis. In this part of the chapter, the data will be processed into meaningful data and analyzed by the researcher.

In the last chapter, the author will conclude the research analysis and provide recommendations on how airline companies can best acquire and retained their companies and stay competitive.

\subsection{Background of the Industry}

\section{Situation Analysis}

The airline service industry is the industry that provides airline travel service. The number of airline service providers in Singapore is enormous. The airlines that fly to Singapore are the Singapore Airlines, Silk Air, Air Asia, Lion Air, Lufthansa and many other airlines. Each of airlines has different ways in competing at the market, like for example there are High quality airline services (i.e. SIA and Lufthansa) and Budget/Value for money airline services (i.e. Lion Air and Tiger Airways).

As it has been mentioned in the introduction stage, the usage of airlines has increased according to International Air Transport Association (IATA). However, due to sharp growth in oil and fuel prices which is vital for airline service it affects the profitability for airline companies (IATA, 2010). Airline service can be purchased through travel agent, official retail-shop and online-website. However, due to advancement of technology (internet), customers nowadays prefer to purchase air-ticket through online as it is the most popular and convenience media.

Furthermore, due to the increasing demand for convenience, speed, quality of service with attractive price, the competition in this industry is becoming stricter. These demands are stimulate by the changes of customers lifestyle, needs and expectations for greater experience in traveling. For example, Singapore which is a country that is famous with its education and medical capability increase the usage of airline service, due to vital needs like education and medication. With the increasing technology and demands, it affects the expectations and innovations for the service which lead to increase in expenditures and sales.

\subsection{Porter's Five Forces Analysis}

Porter's Five Forces Analysis (Porter, 1991) is a framework that is used to analyze the competitive environment within an industry. This model will be used as a guide in examining the five market forces and their impact on the industry. Hence, airline industry will be able to focus more on their opportunities and reducing their threats through evaluation of each force. 


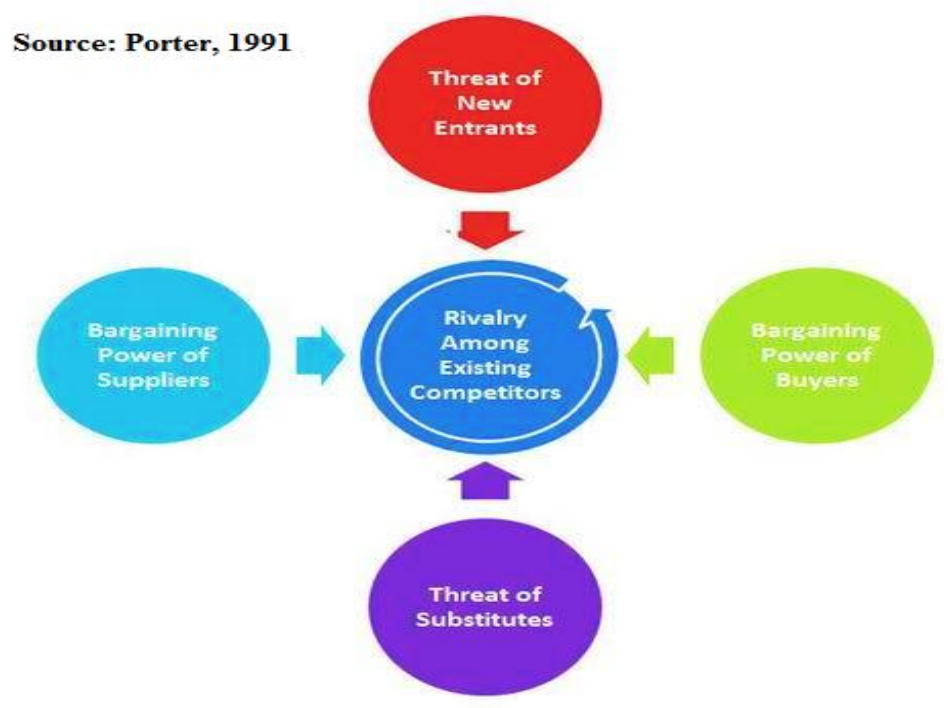

Figure 2.1 Porter Five Forces Model

\subsubsection{Threats of Substitutes (Low)}

Product that able to represent other product function can be defined as substitute product (Wheelen and Hunger, 2002). Currently, there are no perfect substitutes for airline service, as airline service has the best range of destination, time-efficient and convenience. However, the fact that trains and air-transports are substitute is true, but the threat will only be high if it's applied in domestic travel. Currently, the threat of substitutes for airline industry is low. In regards to the threats, Airline Company should keep innovate their service to prevent a perfect substitute.

\subsubsection{Power of Buyer (Moderate-Low)}

The power of buyer can be defined as the ability of customers to affect an industry. This view has been supported in the work of Coulter (2008). The bargaining power of buyer in airline industry is relatively low because the number of buyers for this service is enormous and keeps increasing (IATA, 2010). Additionally, due to different specialty of countries, customers tend to go overseas for particular purpose that the destination country is good at (i.e. Singapore good at Medication), subsequently, going overseas somehow is becoming part of the lifestyle today. Hence, this can also be seen as the service is essential for particular customers which further down the bargaining power of buyer. Looking at another factor which is internet, it allows customers to easily make a comparison through information and price transparency and switch to other airline service. Overall, the bargaining power of buyer is still moderate to low, so organization can take this opportunity to provide excellent service and charge premium price.

\subsubsection{Power of Supplier (High)}

According to Collis and Montgomery (1997), power of supplier can be defined as the ability of suppliers to affect an industry. The power of suppliers in airline industry is relatively high, as fuel is one of the important attributes for airline service. This can be seen as the price of jet fuel price has risen $8 \%$ from January while the usage of airline keeps increasing (IATA, 2010). In addition, as the availability of substitute for fuel has not been found the bargaining power of supplier is still high. However, the availability of jatropha-basedfuel will soon be available substituting the jet-fuel-based which will reduce the bargaining power of supplier in the future (Bloomberg Energy Finance, 2012). Moreover, the bargaining power of suppliers in airline industry is also reduced by the availability of internet. By the use of internet, one can purchase their supplies from suppliers around the world without any geographical boundaries. Hence, currently the power of supplier in this industry is high. In this case, airline firms may want to create good and long term relationship with their suppliers to gain advantages.

\subsubsection{Threats of New Entrants (Low)}

Threats of new entrants are the effect from possible entrants that affects an industry. According to Lynch (2009), potential entrants often come to marketplace when the barrier to entry is low and when profit margins are great. In airline service industry, the barrier is relatively high due to requirements of high capital in entering the industry (i.e. investment on terminal and airplane). Furthermore, as there are already several strong players in the industry, it is hard to enter and established at the market because brand identity in airline service 
need to be good and clear as it is involved with safety (customers will not use unknown airlines as it would be risky). Therefore, it will force the new entrants to spend extra capital to advertise more to fight the strong existing player. Overall, the threat of new entrants is low. Hence, seeing this barrier, existing firms may want to strengthen their branding to further increase the barrier to enter the industry.

\subsubsection{Rivalry among existing Firms (High)}

Rivalry among existing firms refers to the degree in which firm react to moves from other firms within an industry (Pearce and Robinson, 2007). Due to the evolving technology like internet, it allows customers to switch to other company with no more than a click (i.e. moving to other airlines website), this clearly would make player in the industry to be intense. Moreover, due to needs of high investments (i.e. purchasing aircrafts and investment on the technology), it creates high barrier to exit the industry, as the aircrafts and technology that are expensive will be rendered as no-use for other business. While, for company that hire aircrafts for their airline service also need to spend a lot of capital and usually involved with long-contract agreement and need long time to achieve break-even point or gain profit. Additionally, by the arrival of budget airlines which offer value for money airline service it affects the competition in airline industry to become more intense. Overall, the intensity of rivalry among existing firms is high. Therefore, airline firms may want to keep innovate their service and cope-up with the advancing technology so they will be able to provide advance and better service for better position at market.

\section{Literature Review}

According to the industry analysis in the chapter 2, the competition of airline service sectors is strict. Hence, in order for company to stay competitive in the industry, it is advisable for company to know certain strategies. In this literature review, it provides 6 different strategies which are essential to stay competitive.

\subsection{Customer Acquisition}

According to Kotler and Armstrong (2009), finding the right customers that provides a profitable return can be defined as customer acquisition. Customer acquisition is necessary for every companies that start creating a business, expanding their business, products and services, and it is effective in situation where the switching cost is relatively low and repeat purchases are rare .In acquiring customers it is essential for organization to choose the right customers to serve before decide how they can best acquire them. This is particularly important as it is a fact that organization will not be able to serve all customers in every way. Hence, organizations nowadays decide to segment their customers and focus more on customers that they can acquire, satisfy best and bring profitability (Jobber, 2010).

After deciding which segment of customers to target, it is necessary for organization to understand the consumers first. There are three concepts that need to be recognized. Firstly, needs which refer to basic human requirements, in airline case; this can be in a form of necessity to go overseas by airline service. While, wants are the alternative form of needs that are molded by culture and individuality, again in airline case, this would be the desire to have convenience, comfortable and prestigious airline service. Thirdly, wants that are supported by ability to pay is often called demand. It is critical to understand these three concepts which can be seen in the work of Burton, Kotler and Keller (2009) because it is difficult to provide service with better value that lead to successful customer acquisition, if the organization itself does not know what are the customers' needs and wants which will not create strong demand.

Next, Market offerings can be defined as the combination of product, service, experience and information that meet the needs or wants of customers (Lovelock, Patterson and Walker, 2007). Organization need to be careful in creating market offering as by creating an offering, customers tend to create a form of expectations in regards to value and satisfaction based on market offering (Kotler, 2000). For example, SIA offer a great experience and excellent quality level of airline service, customers that hear SIA market offering tend expect high level of airline service. Hence, if the market offering of SIA does not meet the expectations, customers tend to be dissatisfied and switch to competitors. However, in SIA scenario, SIA is able to deliver their service at the promised level which leads to the creation of loyal customers who will share their experience and recommend the service to others. Next, it is also essential to keep in mind that quality of the service is not the only decisive factor. This is true as every customer has their own budget (i.e. for those who want value-formoney service can go for budget airline while those who prefer luxury and prestige will choose SIA). Last but not least, there has been an observation in the work of (Sellers, 1989; Hanan, 2003) that more than 25\% of airline customers are changing airlines annually which indicates that knowing how to acquire customers are extremely essential, particularly due to arrival of budget airlines and the development of technology (internet). 


\subsection{Customer retention}

According to Thompson (2004), customer retention is about increasing the sales by endlessly satisfy and serve the customers so they will keep coming back. In order to ensure the customer retention to be successful, the quality of the service needs to be able to satisfy or go beyond the customer expectations (Zikmund, McLEOD and Gilbert, 2002). Moreover, this view has also been supported in the work of Storbacka and Lehtinen (2001), which said that considering what are the customers' needs for today is not enough. It is also vital to identify or predict the customers future needs.

Customer retention can be done in many ways, like for example by the use of customers' loyalty program (i.e. KrisFlyer program from Singapore airlines which allows customers to redeem free travel in accordance to the mileages that the customers have spent). Another way to retained customers is by keep providing satisfying service or providing the service that beyond the customer expectations to maintain trust and satisfaction of the customers. Additionally, by opening an open feedback from customers to ensure that the company is providing the service that is still relevant and needed with the customers. Customer retention has been argued by Reichheld (1996), that it is less costly compared to customer acquisition, as customers that are satisfied and believe in certain services tend to increase the switching cost in terms of trust and convenience.

\subsection{Customer Relationship Management}

A remarkable technique that involves creating relationship that gives win-win situation for both customers and company can be defined as Customer Relationship Management (Baran, Galka and Strunk, 2008). Customer relationship management involves compiling and analyzing the vast amounts of data of customers which will provide greater insight of the customers' behavior. This will allow a company to treat different customers with different actions accordingly which allow the company to act more efficiently and effectively while retaining their customers. This technique is crucial in retaining customers, as without the existence of knowledge in regards of customers, it is difficult to understand, anticipate and adapt with the customer needs and wants.

\subsection{Customer Satisfaction and Loyalty}

It has been stated in the work of Timm (2011), that a basic sense of caring, concern and competence plays an important role in building customer satisfaction. Customer that are satisfied with a service tend to be loyal and involved with repeat purchases that lead to mouth-to-mouth promotion which will increase the company profitability (Hill et al, 2007). Next, according to Timm (2011), customer satisfaction occurred whenever the customers feel that the price that they pay for certain service is beneficial or worthy. One of the best ways for company to provide satisfaction for customers is by working closely with the customers to ensure the service meet their needs and wants (Lovelock, et al., 2005). This is necessary in order to ensure the service to stay relevant and needed by the target customers and not result in defect customers. For example, tiger airway which is a budget airline stays closely with their target market which is the price conscious customers by keep offering value-for-money airline service.

Next, different customers perceived value from a service subjectively. Therefore, it is essential for company to identify and assess the value perception of key people that are involved in purchasing process (Hollensen, 2003). For example, by using a multiple-person approach which often provide more reliable results rather than single-person studies.

\subsection{Service Recovery}

Service recovery is an extra service that is used to compensate customers due to service failure, converting a defect and existing customers into loyal customers (Cheng, 2000). The fact that services nowadays are still often performed by human, the existence of service failure due to human-error is undeniable. This indicates the importance of service recovery so that the customers that feel dissatisfied because of service failure will feel better. By doing this, customers will feel compensated and delighted which may lead to better promotion for the company. This view has been supported in the work of Cheng (2000). Without service recovery, the unsatisfied customers tend to label the company as no-good which will end up as defect customers and may lead to bad mouth-to-mouth promotion (Zemke and Bell, 2000). Last but not least, company that able to set the service recovery at the right place will ensure that improvement of the image and the name of the company that lead to an increase in profitability.

\subsection{Management and Training of Employees}

As it has been mentioned above, an excellent service that provides satisfaction is essential. However, without the existence of employees that has the ability to perform such service, a great service is just a fantasy (Byars and Rue, 2003). This indicates the importance of choosing the right people to do the job and train them, so they will become company assets instead of liabilities (Slosson, 1999). By providing quality training, it will 
influence the overall motivation and efforts of the employees toward work which will further increase the quality of the service. Management in here refers to company ability to assign the skills that are necessary for each of the employees that have different roles (i.e. the stewardess need to be enhancing with the communication skills and empowered while the technician may be enhance with the evolving technology knowledge). Next, there are two types of feedbacks which are the feedback with hope for the company to improve and feedback that involve with dissatisfaction and irritated feeling. The problem lies in the second type of feedback where customers tend to be thinking and acting emotionally. Hence, it is necessary for the employees (frontline employee) to be able to manage this emotional customer in the right way. JetBlue airlines offer a great example which one of the steward gone berserk and yell at the passengers as the passengers accidentally hit the steward head when taking the luggage (Candiotti, Batchelor and Solomon, 2010). This event occurs possibly due to lack of emotional training, which indicates the essential of training. Moreover, this view is also supported by Jobber and Lancaster (2003), in their studies on learning organizational which revealed that in order for company to survive in the competitive marketplace training is required.

In conclusion, the theories above are crucial in achieving the research objectives. The theories explained about how to acquire and retained customers effectively and efficiently. In order to realize the acquisition and retention, several requirements/knowledge are necessary like for example, understanding customer needs, wants, demand, market offering, customer relationship management, understand how to provide satisfaction and loyalty to customers, understanding the service recovery, training and management. Each of the theories plays their own important roles that support the achievement of successful customer acquisition and retention.

\subsection{Hypotheses}

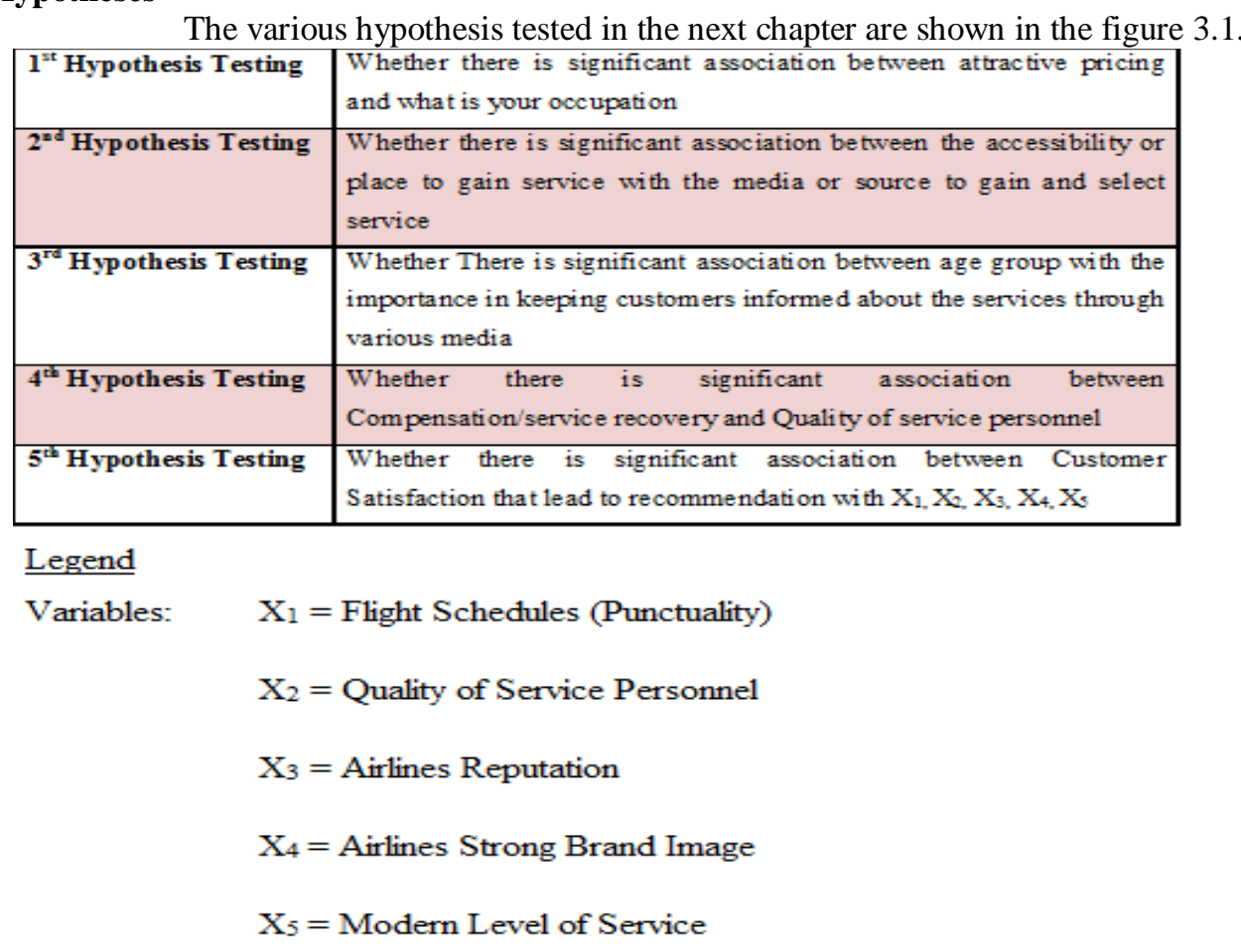

\subsection{Research Methodology}

\section{Methodology}

Generally, there are two types of data which are the primary and secondary data. The primary data is the data that are specifically gathered for the project at hand (Zikmund, 2003). The primary data can be divided in two categories which are the qualitative and quantitative data. Next, secondary data refer to the data that have been gathered or used previously for project other than the one at hand (Sharma, 2009). In doing research methodology, it is essential for the researcher to ensure that the result of this research to be valid and as accurate as possible. Therefore, the author will provide techniques to acquire the data, choice in acquiring the data and state several pros and limitations of the chosen research technique. 


\subsubsection{Primary Research Data}

One of the best reasons to use primary data is that this data is closely relevant with the research's objectives. This is because the data is specifically searched solely for the objectives which mean the time; problems and market-situation are fresh (relevant with the project at hand). However, it is also important to take note that primary research also provides drawbacks which are more time-consuming and more costly. As it has been mentioned above that there are two types of primary research which are qualitative and quantitative research.

\subsubsection{Qualitative Research}

Qualitative research can be defined as a research that addresses the marketing objectives without depending on numerical measurement (Zikmund and Babin, 2009). Qualitative research is very appropriate when the research focus on a depth understanding of motivation. This is because qualitative research allows the researcher to see the emotion and hear the language used by the respondents. According to Szwarc (2005), this type of research usually shapes in a form of observational research, in-depth interview, camera journals and behavior mapping.

\subsubsection{Quantitative Research}

Quantitative research is a research that depends on numerical measurement and generalizing it across the group of people (Zikmund and Babin, 2009). It is necessary for the researcher to have big sample for this type of research in order to reduce the chance of having errors. Quantitative research is most appropriate when the objectives of the research involve a managerial action standard. Quantitative research is usually shapes in a form of consumer panels, consumers' surveys, syndicated surveys, omnibus surveys and tracking (Szwarc, 2005). For further comparison please refer to figure 4.1.

\section{Figure 4.1}

\begin{tabular}{|c|c|c|}
\hline Qualitative Research & Research Aspect & Quantitative Research \\
\hline $\begin{array}{l}\text { Discover Ideas, Used in } \\
\text { Exploratory Research with } \\
\text { General Research Objects }\end{array}$ & Common Purpose & $\begin{array}{l}\text { Test Hypotheses or Specific } \\
\text { Research Questions }\end{array}$ \\
\hline Observe and interpret & Approach & Measure and Test \\
\hline Unstruc tured, Free-Forms & Data Collection Approach & $\begin{array}{l}\text { Structured Response } \\
\text { Categ ories Provided }\end{array}$ \\
\hline $\begin{array}{l}\text { Researcher is intimately } \\
\text { involved. Results are } \\
\text { subjective. }\end{array}$ & Research Independence & $\begin{array}{l}\text { Researcher Uninvolved } \\
\text { Observer. Results Are } \\
\text { Objective. }\end{array}$ \\
\hline $\begin{array}{l}\text { Small Samples - often in } \\
\text { Natural Settings }\end{array}$ & Samples & $\begin{array}{l}\text { Large Samples to produce } \\
\text { Generalizable Results (Results } \\
\text { that Apply to Other Situations) }\end{array}$ \\
\hline Exploratory Research Designs & Most Often Used & $\begin{array}{l}\text { Descriptive and Causal } \\
\text { Rese arch Designs. }\end{array}$ \\
\hline
\end{tabular}

Source : Zikmund and Babin, 2009

\subsubsection{Secondary Research Data}

Secondary research data is a research that uses an existing data that have been used or existed before (Hubbard, 2010). Some of the sources for secondary data are the books, journal, company records and news articles. The availability of the data and efficiency in terms of time are the major reasons for most authors use the secondary data. Additionally, this approach is also less expensive compared to primary data research which involves in interviewing or delivering surveys. Furthermore, through this technique the researcher can bring in different perspective from different people and analyse it to further understand the data. However, the drawback of using such data is that the data are often irrelevant to the objectives (i.e. outdated and not timely data) as the data is not gathered specifically for the project at hand. Not to mentioned that, as it allows the researcher to bring different perspective from different source/people it may also result in a conflict between data (Berman and Evans, 2010). 


\subsection{Choice of Research Methodology}

A primary quantitative research and secondary data are selected by the author because it is essential to use both in order to wholly solve the problems (Kotler and Keller, 2012). The primary research is carried out by delivering survey questionnaire physically and online to get respondents. The questions asked are closed-ended questions; this is done in order to minimize the probability of having error response. Furthermore, a secondary data research is also carried out; this research source is from journal, books and article to further support the research. Lastly, once the data has been collected, the XLD Software will be used to analyze and interpret the validity of the hypothesis tests.

\subsection{Survey Design}

The survey is designed in a simple way and structured manner to reduce the chances of ambiguity so that the respondents can understand and answer the questions with ease.

There are total of 12 questions in the survey which divided into four sections. The first section is about the demographic questions, which aim to identify whether these factors are affecting the choice of customers for airline service. The next section objective is to identify what are the things that customers look and take it as important in airline service. The third section aim to identify the source or media that customer uses in finding airline service. The last section aim to identify; what are the factors that make customers to be attracted with the service, the probability of doing repeat purchases and recommend the service to others. Please refer to appendix 1.

\subsection{Pre-Test}

Before the questionnaire was officially distributed, a pre-test on 3 respondents has been done. This is to check whether there was ambiguity and problems with the questions. By doing this, it allows the researcher to adjust the questions accordingly before a full scale distribution was done.

\subsection{Sample Size}

A sample size of 80 has been chosen, targeting respondents from 21 years old and above. The questionnaires are targeted to friends, relatives, ex-colleagues and random respondents. Each of the respondents has different backgrounds which provide different answers with more accuracy in the results.

\subsection{Evaluation of the Survey Results}

After all data has been collected from primary quantitative survey and secondary data (books, journal and article), afterwards Microsoft Excel XL Data analysis will be used to gather and test the validity of the hypotheses in the next chapter. Several tests such as cross tabulation, correlation and multiple regressions will be carried out.

\subsection{Bias and Limitation of Research Process}

The first limitation for this research is the small number of sample size of 80 which raise the standard deviation. This is due to limited time and cost which prevent the author to gain a bigger sample size for the survey. Furthermore, as the author has no control on how the respondents interpret the questionnaire and answer, it may lead to inaccurate result or misinterpretation. Last but not least, the distribution of the questionnaire is not distributed equally in terms of demographic group which may create a biased result.

\section{Finding and Analysis}

In this chapter, the data that have been gathered will be tabulated and analyze with the use of Microsoft Excel XL Data Analyst to achieve the objective research.

\subsection{Demographics Percentage Analysis}

These analyses display the response from demographic questionnaire. The total numbers of respondents are 80. Please refer to Figure 5.1 for Age Group; Occupation to Figure 5.2; and Monthly income level to Figure 5.3. 
Figure 5.1 Demographics Percentage Analysis - Age

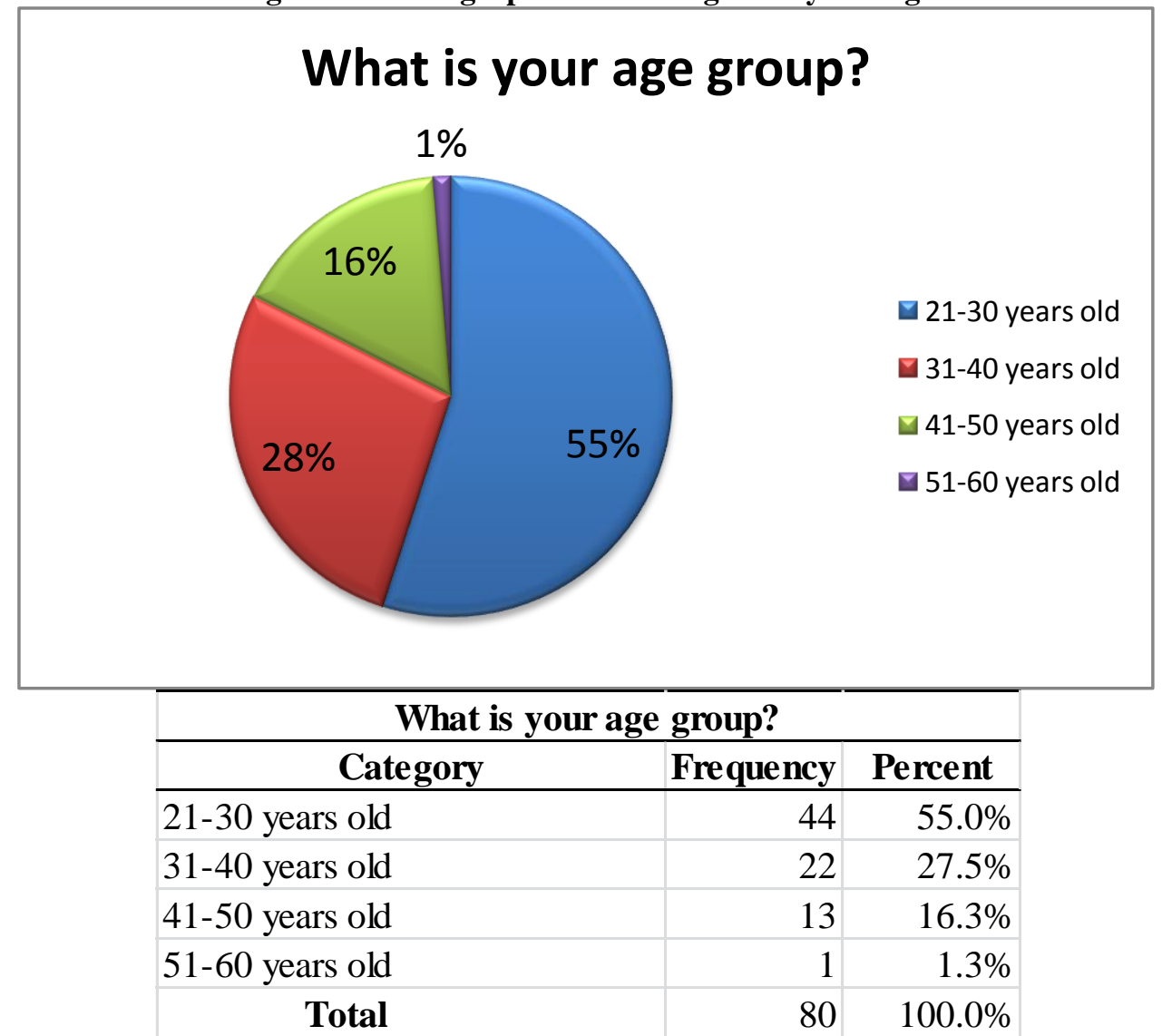

In terms of age, the figure above indicates that the questionnaire catch all the range of age with the majority of 21-30 years old group.

Figure 5.2 Demographics Percentage Analysis - Occupation

\begin{tabular}{|l|l|}
\hline What is your occupation? \\
\\
\end{tabular}




\begin{tabular}{|c|c|c|}
\hline \multicolumn{3}{|c|}{ What is your occupation? } \\
\hline Category & Frequency & Percent \\
\hline Professionals & 11 & $13.8 \%$ \\
\hline executives & 26 & $32.5 \%$ \\
\hline sales/administrative & 2 & $2.5 \%$ \\
\hline students & 40 & $50.0 \%$ \\
\hline others & 1 & $1.3 \%$ \\
\hline Total & 80 & $100.0 \%$ \\
\hline
\end{tabular}

From the figure 5.2, it can be seen that the majority of the respondents belong to students (50\%), Executives (32.5\%), Professionals (13.8\%). While, Sales/Administrative and others are at $3 \%$ and $1 \%$ respectively.

Figure 5.3 Demographics Percentage Analysis - Monthly Income Level

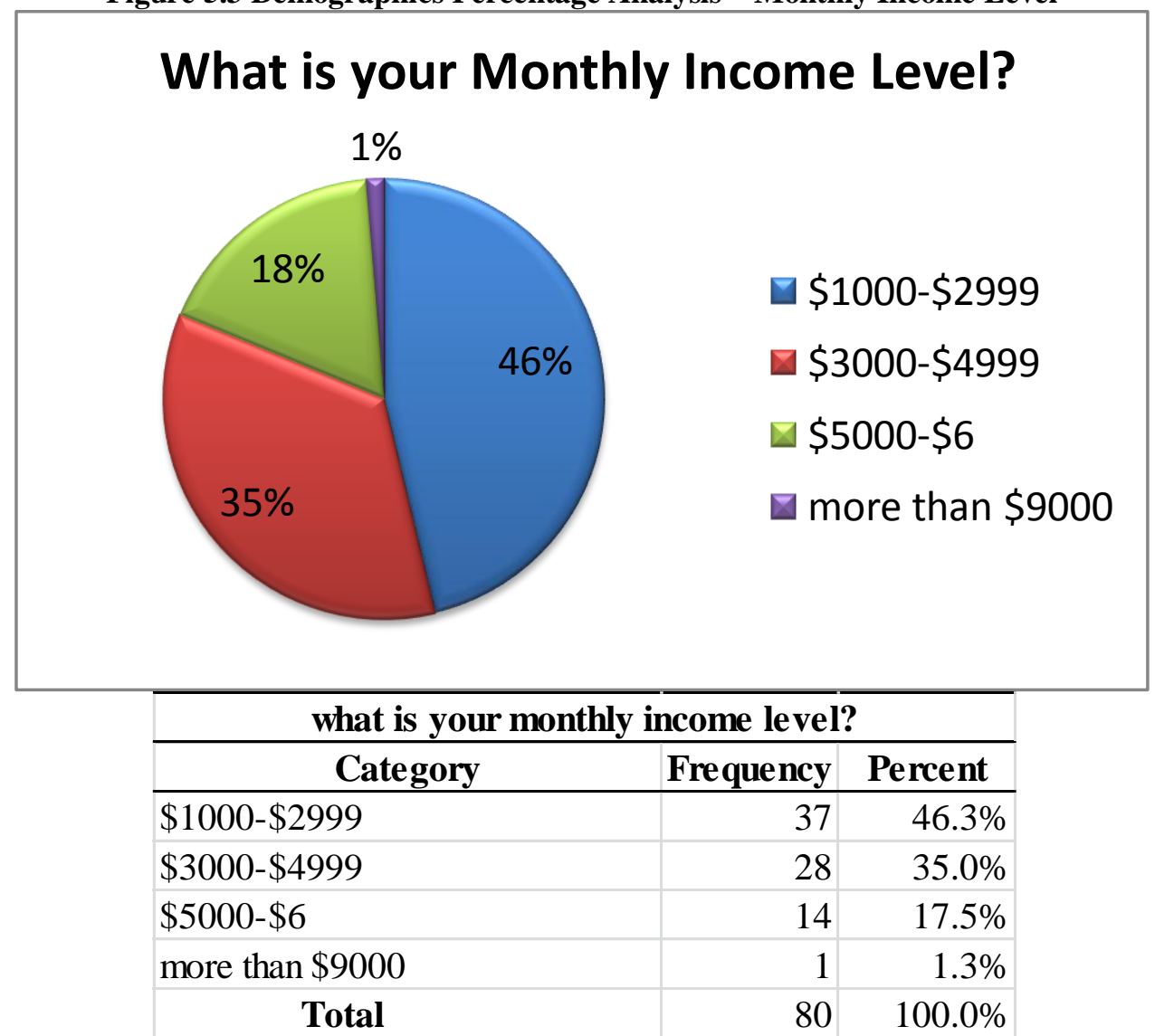

From figure 5.3, it shows that the only category that has small respondent is "more-than $\$ 9000$ category", while the others categories are spread thoroughly.

5.2 Cross Tabulation between does attractive price attract customers and what is your occupation.

Cross tabulation is a statistical measurement technique to analyze a relationship between two variables (Proctor, 2005) .This test was conducted to identify whether there is a relationship or not between the age group and the choice of media source in choosing airline. 


\section{Figure 5.4}

Crosstabulation Analysis (No table indicates an error in your data)

CROSSTABS VARIABLES ANALYZED

does an attractive price is important?

With...

What is your occupation?

\begin{tabular}{|l|l|l|l|l|l|l|}
\hline Observed Frequencies & & & & \\
\hline & Professionals executives & sales/adminis students & others & Grand Total \\
\hline neutral & 3 & 6 & 0 & 2 & 0 & 11 \\
\hline important & 7 & 16 & 2 & 23 & 1 & 49 \\
\hline very important & 1 & 4 & 0 & 15 & 0 & 20 \\
\hline \multicolumn{1}{|c|}{ Grand Total } & 11 & 26 & 2 & 40 & 1 & 80 \\
\hline
\end{tabular}

\begin{tabular}{|ccc|}
\hline \multicolumn{3}{c}{ Statistical Values } \\
\hline Chi Sq & $d f$ & Sig \\
\hline 11.91 & 8 & 0.16 \\
\hline
\end{tabular}

There is NO significant association between these two variables.

(95\% level of confidence)

\section{$1^{\text {st }}$ Hypothesis Testing}

H0: There is no significant association between attractive pricing and what is your occupation (if $\mathrm{p}>0.05$ ).

$\mathrm{H} 1$ : There is significant association between attractive pricing and what is your occupation (if $p<0.05$ ).

\section{Decision: Accept HO}

As it can be seen from the figure 5.4, the Sig figure is 0.16 which is higher than 0.05 which indicates that no matter what job it is (professionals to students or others) majority chose agree and strongly agree that attractive pricing are attention-grabbing. One of the best explanations for this is that every customer tends to be very delighted and interested for a service whenever they receive extra benefit which can be in form of discount and promotion. Hence, it is essential for airline companies to take note that promotion is one of the key factors in grasping the customers at marketplace.

5.3 Cross Tabulation between the accessibility-or- place to gain service with the media or source to gain and select service.

Figure 5.5

Crosstabulation Analysis (No table indicates an error in your data)

CROSSTABS VARIABLES ANALYZED

does the accessibility or place to gain service is important?

With... what media or source did you often use in searching for airline?

\begin{tabular}{|l|c|c|c|c|c|}
\hline Observed Frequencies & & & & \\
\hline & internet & newspapaer & television & relatives & Grand Total \\
\hline trivial & 10 & 0 & 0 & 0 & 10 \\
\hline neutral & 25 & 2 & 0 & 2 & 29 \\
\hline important & 4 & 13 & 1 & 15 & 33 \\
\hline very important & 0 & 0 & 1 & 7 & 8 \\
\hline \multicolumn{1}{|c|}{ Grand Total } & 39 & 15 & 2 & 24 & 80 \\
\hline
\end{tabular}

There IS a significant association between these two variables. (95\% level of confidence)

\begin{tabular}{|c|c|c|c|c|c|}
\hline \multicolumn{6}{|l|}{ Column Percents } \\
\hline & internet & newspapaer & television & relatives & Grand Total \\
\hline trivial & $26 \%$ & $0 \%$ & $0 \%$ & $0 \%$ & $13 \%$ \\
\hline neutral & $64 \%$ & $13 \%$ & $0 \%$ & $8 \%$ & $36 \%$ \\
\hline important & $10 \%$ & $87 \%$ & $50 \%$ & $63 \%$ & $41 \%$ \\
\hline very important & $0 \%$ & $0 \%$ & $50 \%$ & $29 \%$ & $10 \%$ \\
\hline Grand Total & $100 \%$ & $100 \%$ & $100 \%$ & $100 \%$ & $100 \%$ \\
\hline \multicolumn{6}{|l|}{ Row Percents } \\
\hline & internet & newspapaer & television & relatives & Grand Total \\
\hline trivial & $100 \%$ & $0 \%$ & $0 \%$ & $0 \%$ & $100 \%$ \\
\hline neutral & $86 \%$ & $7 \%$ & $0 \%$ & $7 \%$ & $100 \%$ \\
\hline important & $12 \%$ & $39 \%$ & $3 \%$ & $45 \%$ & $100 \%$ \\
\hline very important & $0 \%$ & $0 \%$ & $13 \%$ & $88 \%$ & $100 \%$ \\
\hline Grand Total & $49 \%$ & $19 \%$ & $3 \%$ & $30 \%$ & $100 \%$ \\
\hline
\end{tabular}




\section{$2^{\text {nd }}$ Hypothesis Testing}

H0: There is no significant association between the accessibility or place to gain service with the media or source to gain and select service (if $\mathrm{p}>0.05$ ).

H1: There is significant association between the accessibility or place to gain service with the media or source to gain and select service (if $\mathrm{p}<0.05$ ).

\section{Decision: Accept H1}

As figure 5.5 has shown that the Sig number is at 0.00 which is lower than 0.05 , this indicates that there is a relationship between the accessibility or place to gain service with the media or source to gain and select service. Discussing on internet, which most of the respondents choose trivial and neutral. It is most likely because the customers itself are ordering their airline ticket through internet which allow them to get air-ticket without going to travel agent or airline store. On the other hand, customers that often gain information and select airline service from relatives, television and newspaper believes that the accessibility of a store is very important as they need to go to the physical store itself to purchase the air-ticket.

\subsection{Cross Tabulation between the age group with the importance in keeping customers informed about} the services through various media.

Figure 5.6

Crosstabulation Analysis (No table indicates an error in your data)

\section{CROSSTABS VARIABLES ANALYZED}

What is your age group?

With...

does keeping customers informed through catalogues, monthly newsletter,advertisement etc are important?

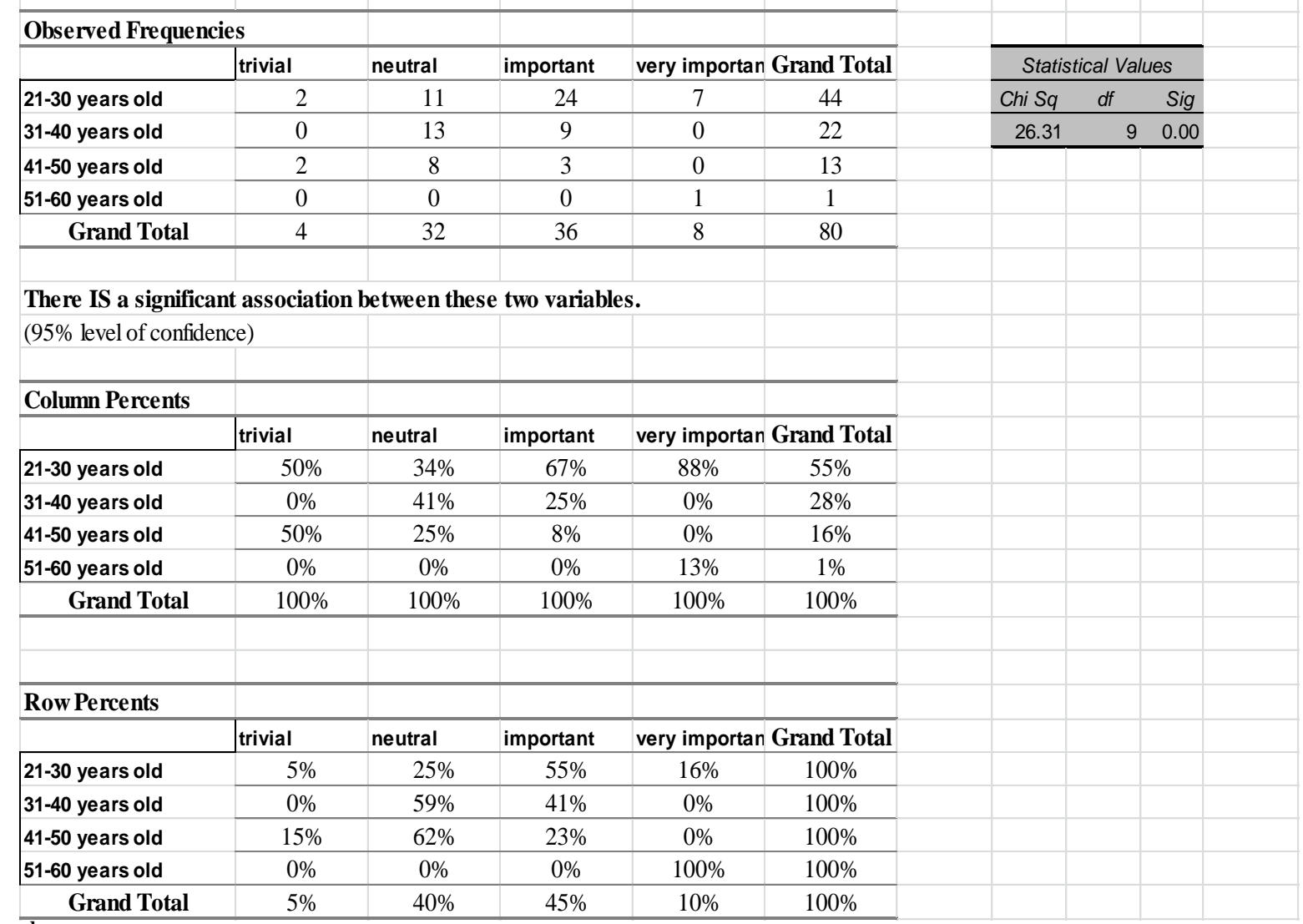

$3^{\mathrm{rd}}$ Hypothesis Testing

H0: There is no significant association between age group with the importance in keeping customers informed about the services through various media (if $\mathrm{p}>0.05$ ).

H1: There is significant association between age group with the importance in keeping customers informed about the services through various media (if $\mathrm{p}<0.05$ ). 


\section{Decision: Accept H1}

The author accepts $\mathrm{H} 1$ because the Sig level is at 0.00 which is lower than 0.05 . This indicates that there is significant relationship between these two variables. According to figure 5.6, keeping customers informed through various media is essential for customers from 21-50 age groups. However, it can be seen that as the group age goes up from 21-50, the importance of keeping customers informed through various media is becoming less and less. This is because young customers tend to check e-mail, newsletter and advertisement when they are looking for airline service. Whereas, the upper age group tend to rely more on their relatives to gain information about service airline which make informing them from various media for service is inefficient and ineffective.

\subsection{Correlation Test Analysis on Compensation/Service Recovery and Quality of service personnel.}

Correlation test analysis can be defined as a measurement that determines the relationships of two or more variables (Burns and Bush, 2005).

Figure 5.7

\section{Correlation Analysis Results}

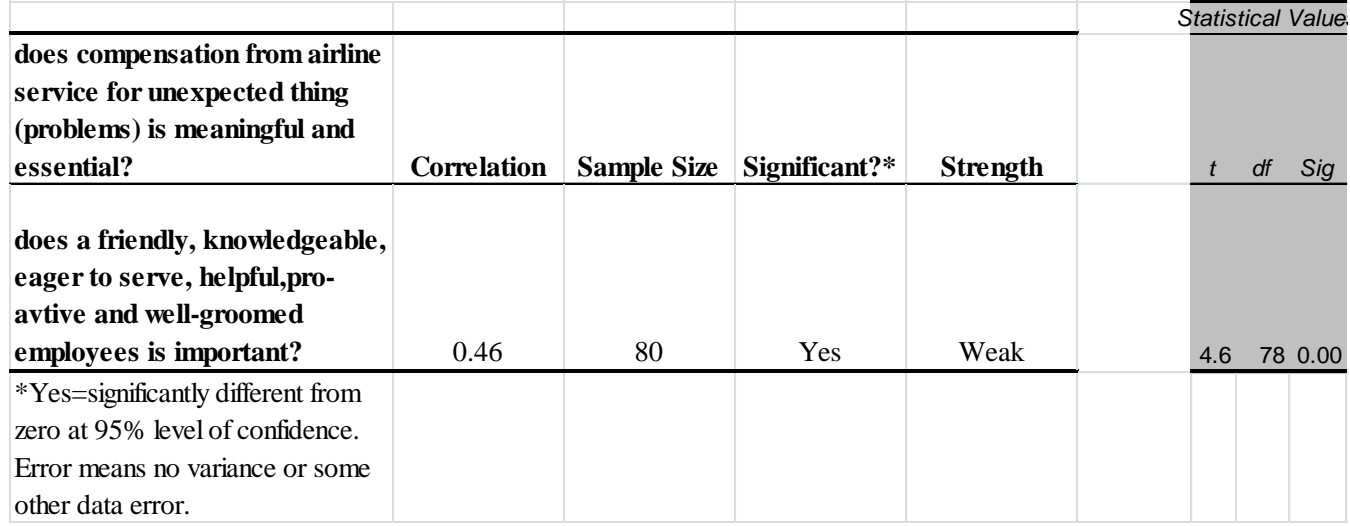

\section{$4^{\text {th }}$ Hypothesis Testing}

H0: There is no significant association between Compensation and Quality of service personnel (if $p>0.05$ ).

H1: There is significant association between Compensation and Quality of service personnel (if $p<0.05$ ).

\section{Decision: Accept H1}

The author chooses to accept $\mathrm{H} 1$ because the Sig figure is 0.00 which is lower than 0.05 . This depict that there is a relationship between compensation and quality of service personnel. One of the possible explanations for this is that compensation often requires for the customers to directly involve with service personnel. Hence, the quality of service personnel in delivering the service recovery depends on the quality of the personnel. This indicates the important for airline companies to ensure that their workers need be equipped with certain skills to ensure the quality of the compensation/service recovery.

\subsection{Multiple Regression Analysis to identify the factors that affecting customers in choosing airlines}

Multiple Regressions can be defined as a method to determine the relationship of a dependent variable with independent variables (Churchill and Brown, 2007). 


\section{Figure 5.8}

\begin{tabular}{|c|c|c|c|c|c|c|c|c|c|}
\hline Trimmed Regression Analysis Res & Its (Backwar & Stepwise) & & Stati & istical & Ies & & & \\
\hline Dependent Variable & Total Cases & 80 & & $F$ & dfReg & Tot & Sig & $R s q$ & SErrY \\
\hline $\begin{array}{l}\text { if the attributes from the previous } \\
\text { question from behaviour } 1,2,3,4 \text { are } \\
\text { fullfilled and results in satisfaction } \\
\text { will you recommend this airline? }\end{array}$ & & & & 23.8 & 5 & 74 & 0.00 & 0.62 & 0.35 \\
\hline Independent Variable(s) & Coefficient & Standardized & Significant?* & $t$ & Sig & & & & \\
\hline $\begin{array}{l}\text { does having a flight schedule right } \\
\text { on time important? }\end{array}$ & 0.22 & 0.23 & Yes & 2.8 & 0.01 & & & & \\
\hline $\begin{array}{l}\text { does a friendly, knowledgeable, } \\
\text { eager to serve, helpful,pro-avtive and } \\
\text { well-groomed employees is } \\
\text { important? }\end{array}$ & 0.25 & 0.26 & Yes & 2.7 & 0.01 & & & & \\
\hline $\begin{array}{l}\text { is the reputation of the company or } \\
\text { airlines are important? }\end{array}$ & 0.39 & 0.44 & Yes & 4.9 & 0.00 & & & & \\
\hline $\begin{array}{l}\text { does strong brand image and } \\
\text { internationnal well known brands } \\
\text { important? }\end{array}$ & -0.23 & -0.29 & Yes & -4.0 & 0.00 & & & & \\
\hline $\begin{array}{l}\text { are modern \& trendy service that } \\
\text { meet perosnal preferencen and need } \\
\text { important? }\end{array}$ & 0.15 & 0.17 & Yes & 2.2 & 0.03 & & & & \\
\hline Intercept & 0.85 & & No & 1.7 & 0.08 & & & & \\
\hline
\end{tabular}

${ }^{\star} 95 \%$ level of confidence

The formula is for calculating satisfaction that lead to recommendation is

$Y($ satisfaction that lead to recommendation $)=a+B_{1}\left(X_{1}\right)+B_{2}\left(X_{2}\right)+B 3\left(X_{3}\right)+B 4\left(X_{4}\right)+B 5\left(X_{5}\right)$

$\mathrm{Y}$ (satisfaction that lead to recommendation $)=0.85+(0.22)\left(X_{1}\right)+(0.25)\left(X_{2}\right)+(0.39)\left(X_{3}\right)+(-0.23)\left(X_{4}\right)+(0.15)($

$\mathrm{X}_{5}$ )

Legend

Variables: $\quad \mathrm{X}_{1}=$ Flight Schedules (Punctuality)

$\mathrm{X}_{2}=$ Quality of Service Personnel

$\mathrm{X}_{3}=$ Airlines Reputation

$\mathrm{X}_{4}=$ Airlines Strong Brand Image

$5^{\text {th }}$ Hypothesis Testing

$\mathrm{X}_{5}=$ Modern Level of Service

H0: There is no significant association on Customer Satisfaction that lead to recommendation by any variables (if $\mathrm{p}>0.05$ ).

H1: There is significant association on Customer Satisfaction that lead to recommendation by one or more variables (if $\mathrm{p}<0.05$ ).

\section{Decision: Accept $\mathrm{H1}$}

Based on Figure 5.7, all the variables shows that the Sig figure is lower than 0.05 which means there is a significant association on Customer Satisfaction that lead to recommendation by one or more variables. Furthermore, The Rsq (Adjusted R-Square) value is 0.62. This indicates that $62 \%$ change in Customer Satisfaction that lead to recommendation is due to variables above in the Figure 5.7. Below each of the variables will be discussed more in details.

$\underline{X}_{1}$ Flight Schedules (Punctuality)

$\mathrm{X}_{1}$ is the third factor that influence the customer satisfaction that lead to recommendation with a coefficient of 0.22 . Based on the test result, the punctuality of the flight schedules has a positive coefficient which means it affects the chance of satisfied customer to recommend the airline service. By offering a punctual airline service, customers will have a pleasant trip which will lead to customer satisfaction and recommendation. Punctual airline service is critical for all customers, as having sudden changes in flight schedules often affects the customers which may create problems for them that lead to dissatisfaction and bad mouth-to-mouth promotion.

$\underline{X}_{2:}$ Quality of Service Personnel

According to the result, the quality of service personnel is essential in affecting the chance of satisfied customer to recommend the airline service. The quality of service for a service company is a vital point, which indicates the need for excellent and quality personnel to do high level of service is critical. By using an excellent quality of personnel, even a normal level of service can become a great service which will lead to more customer satisfaction; allow them to patronize for the service and recommend the service to others, hence increase the profitability of the company.

$\underline{X}_{3:}$ Airlines Reputation 
Based on the test result, the reputation of airlines has the biggest influence on the customer's satisfaction that lead to recommendation with a staggering $44 \%$. Reputation is an intangible asset that only can be built through delivering excellent service with stability for a long period of time. This means that customers tend to choose an airline service based on reputation as it offers better possibility of having satisfaction compared to unknown airlines which are dangerous or may lead to dissatisfaction. And of course, the tendency for customers to recommend is high when customers are satisfied with the service which indicates building a great reputation for Airline Company is another vital point.

\section{$\underline{X}_{4}$ : Airline Strong Brand Image}

According to the test result, airline strong brand image has a negative coefficient. This may refer to the possibility that strong brand image is not a strong determinant factor for customers in resulting customers satisfaction and recommendation. Furthermore, this may be due to different perceived value for different customers (i.e. customers value for money will value good-pricing with normal quality of service compared to expensive-pricing with excellent quality of service). Hence, it is necessary to do a further research for this relationship in order to study further in regards to the impact of strong brand image.

\section{$\underline{X}_{5:}$ Modern Level of Service}

Modern service also has an impact to customers' satisfaction that lead to recommendation with coefficient of 0.15 . The modern service here may refer to the fact service need to cope up with the changes that happen in the market place. Like for example, as the technology advance so quickly, it is necessary for airline companies to apply the latest technology to provide better service for customers that lead to satisfaction and recommendation. In this case, improving the check-in process and providing entertainment or facilities like games, movies and inflight calling will attract different customers with different needs. Overall, it is necessary and important for airline companies to cope up with the changes in the marketplace to be able to provide satisfaction to customers.

\section{Conclusion and Recommendations}

\subsection{Conclusions}

This research has allowed the author to understand the customers' mindset and preference when they are considering airlines. There are several important factors that have been identified which need to be highlighted in grasping and retaining the customers.

Firstly, in regards to the analysis on the attractive pricing affect customers differently according to their occupation. There is no relationship within these two variables which means every customers love attractive price despite having different occupations. Hence, it is essential for airline companies to ensure that they have the best pricing strategies to grasp the customers.

Moving on to the next finding which proves there is a relationship between the accessibility/place to gain service with the media or source that are used in searching airlines. This highlight the needs for airline companies to provide great accessibilities for customers both physically (store) and Online media service. This is necessary and essential as different type of media that customers use have different impact on the needs of accessibilities/place to gain service.

In addition, it is also essential for airline companies to know that informing customers about airline service need to be differentiated. Informing younger customers through various media may be effective and efficient as they are aware of it, while for older customers; relying mouth-to-mouth promotion is more efficient and effective, as they are rarely using media like newsletter, email and other media.

Furthermore, according to correlation analysis, the essence of the quality of service personnel affects the service recovery/compensation result. This highlights the needs for airline companies to train their workers so that they will be able to deliver the service recovery that can lead to better satisfaction and recommendations. Moreover, in regards to factors that affecting customer's satisfaction that leads to recommendation, attributes like punctuality, quality of service personnel, reputation, strong brand image and modern service plays an important role in achieving customer's satisfaction and recommendation. This indicates the need for companies to be able to provide great service with consistency to provide punctuality and establish reputation for long term; able to cope-up with the changes/development in the marketplace in order to create a strong brand image and ensure that the service that they offer are realized by enhancing the quality of service personnel that perform and support the service.

In Conclusion, it is essential to focus on all the aspects above in order to be able to acquire and retained customers which lead to recommendations thus, increasing the overall profitability for the companies for the present and in the long term. 
Books

[1]. Baran, G. Galka, R. and Strunk, D., 2008. Principles of Customer Relationship Management. Mason: Thompson South-Western.

[2]. Berman, B. and Evans, J.R., 2010. Retail Management: a strategic approach. $11^{\text {th }}$ ed. New Jersey: Prentice Hall.

[3]. Burns, A. C. and Bush, R.F., 2005. Marketing Research: Online Research Applications. $4^{\text {th }}$ ed. New Jersey: Pearson Education, Inc.

[4]. Burton, S. Kotler, P. and Keller, K.L., 2009. Marketing management / Suzan Burton; Philip Kotler; Kevin Lane Keller. NSW: Pearson Education Australia.

[5]. Byars, L.L. and Rue, L.W., 2003. Human Resource Management. $7^{\text {th }}$ ed. New York: McGraw-Hill Companies, Inc.

[6]. Cheng, P.L.K., 2000. Strategic Customer Management Enhancing Customer Retention and Service Recovery. 4 Pang Seng Road Singapore: BusinessCraft Consultancy.

[7]. Churchill, G.A. and Brown, T.J., 2007. Basic Marketing Research. $6^{\text {th }}$ ed. Ohio: Thompson South-Western

[8]. Collis, D.J. and Montgomery, C.A., 1997. Corporate Strategy Resources and the scope of the Firm. Chicago: McGraw-Hill Irwin.

[9]. Coulter, M., 2008. Strategic Management in Action. $4^{\text {th }}$ ed. New Jersey: Pearson Education Inc.

[10]. Hanan, M., 2003. Consultative Selling. $7^{\text {th }}$ ed. New York: Amacom

[11]. Hubbard, W., 2010. How to Measure Anything: Finding the Value of Intangibles in Business. $2^{\text {nd }}$ ed. Boston: John Wiley and Sons.

[12]. Hill, N. Roche, G. and Allen, R., 2007. Customer Satisfaction: The customer experience through the customer's eyes. $1^{\text {st }}$ Ed. UK: Cogent Publishing

[13]. Jobber, D., 2010. Principles and Practice of Marketing. $6^{\text {th }}$ ed. London: McGraw-Hill Education.

[14]. Kotler, P. and Armstrong. G., 2009. Principles of Marketing.13 ${ }^{\text {th }}$ ed. London: Pearson Education.

[15]. Kotler, P., 2000. Marketing Management. New Jersey: Prentice-Hall, Inc.

[16]. Kotler, P. and Keller, K.L., 2012. Marketing Management.14 ${ }^{\text {th }}$ ed. Upper Saddle River: Pearson Education.

[17]. Lovelock, C.H. et al., 2005. Services marketing in Asia. $2^{\text {nd }}$ ed. Prentice Hall: Singapore.

[18]. Lovelock, C.H. Patterson, P.G. and Walker, R.H., 2007. Services Marketing : an Asia-Pacific and Australian perspective. $4^{\text {th }}$ ed. NSW: Pearson Education Australia.

[19]. Lynch, R., 2009. Strategic Management. $5^{\text {th }}$ ed. New York: Prentice Hall.

[20]. Palmer, A., 2011. Principles of Service Marketing. $6^{\text {th }}$ ed. London: McGraw-Hill-Education.

[21]. Pearce, J.A. and Robinson, R.B., 2007. Strategic Management Formulation, Implementation, and Control. 10 ${ }^{\text {th }}$ ed. Boston: McGraw-Hill Irwin.

[22]. Proctor, P., 2005. Essentials of Marketing Research. $4^{\text {th }}$ ed. London: Pearson Education Limited.

[23]. Reichheld, F.F., 1996. The Loyalty Effect: the hidden force behind growth, profits, and lasting value. Boston: Bain \& Company, Inc.

[24]. Sellers, P., 1989. Getting customers to love you, Pp.38-49

[25]. Sharma, K., 2009. Marketing Management, How to Create, Win and Dominate Markets. India: Global India Publications.

[26]. Slosson, J., 1999. Hiring the Right People. High School Magazine, 7 (2), pp.26-30.

[27]. Storbocka, K. and Lehtinen, J.R., 2001. Customer Relationship Management : Creating Competitive Advantage through Win-Win Relationship Strategies. New York: McGraw-Hill Education.

[28]. Thompson, H., 2004. Who stole my customer? : winning strategies for creating and sustaining customer loyalty. New Jersey: Pearson Education, Inc.

[29]. Timm, P.B., 2011. Customer Service: Career Success Through Customer Loyalty. $5^{\text {th }}$ ed. New Jersey: Pearson Education, Inc.

[30]. Wheelen, T.L. and Hunger, J.D., 2002. Strategic Management and Business Policy. $8^{\text {th }}$ ed. New Jersey: Pearson Education.

[31]. Zemke, R. and Bell, C.R., 2000. Knock your socks off service recovery. New York: Amacom.

[32]. Zikmund, W.G. McLEOD, R. and Gilbert, F.W., 2003. Customer Relationship Management: Integrating Marketing Strategy and Information Technology. New Jersey: John Wiley and Sons, Inc.

[33]. Zikmund, W.G., 2003. Exploring Marketing Research. $8^{\text {th }}$ ed. Ohio: South-Western.

[34]. Zikmund, W.G. and Babin, B.J., 2009. Exploring Marketing Research. $10^{\text {th }}$ ed. Ohio: South-Western.

\section{Website}

[1]. IATA, 2012. Demand Growth Compromised by High Oil Prices. [Online] Available at: <http://www.iata.org/pressroom/pr/pages/2012-05-02-01.aspx> [Accessed 20 may 2012].

[2]. Candiotti, S. Batchelor, L. and Solomon, J., 2010. Flight attendant charged with opening emergency evacuation chute. CNN TRAVEL, [online]9 august. Available at: <http://articles.cnn.com/2010-08-09/travel/new.york.escape.chute.opened_1_flight-attendant-jet-blueflight-emergency-slide? s=PM:TRAVEL> [Accessed 05 June 2012].

\section{Questionnaire}

\section{Appendix 1}

Dear respondent, firstly I would like to thank you for taking your time to fill the questionnaire. This questionnaire is to study and comprehend more in regards to customers' acquisition and retention in airline service industry. All the information will be kept confidential and used for strictly academic purposes only.

\section{Please mark $(\checkmark)$ in the appropriate box for your answer, unless otherwise stated.}

\section{A. Demographics}

1. What is your Age Group?

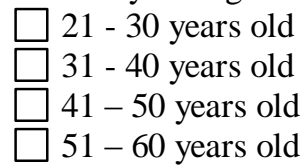

2. What is your Occupation?
$\square$ Professionals
Executives 
$\square$ Sales / Administrative

$\square$ Technical

$\square$ Retiree

$\square$ Students

$\square$ Others

3. What is your monthly income level?
$\square \$ 1,000-\$ 2,999$
$\square \$ 3,000-\$ 4,999$
$\$ 5,000-\$ 6,999$
$\$ 7,000-\$ 8,999$
More than $\$ 9,000$

\section{B. Customer Expectation}

1. Firstly, rank the airline services brand in terms of preference with a scale of $1=$ Least Preferred to 5=Most Preferred.

\begin{tabular}{|l|l|l|l|l|l|}
\hline Brands & $\mathbf{1}$ & $\mathbf{2}$ & $\mathbf{3}$ & $\mathbf{4}$ & $\mathbf{5}$ \\
\hline \hline Singapore Airlines & & & & & \\
\hline \hline Lufthansa & & & & & \\
\hline \hline Jet Star & & & & & \\
\hline \hline Tiger Airways & & & & & \\
\hline \hline Others & & & & & \\
\hline
\end{tabular}

2. How often do you patronize with the most preferred airline service above?

$\square$ At least once in the past 6 months

$\square$ At least once in the past 3 months

$\square$ At least once in the past 1 month

$\square$ Frequently

3. Next, rank the factors below that are important in selecting airline service from a scale of 1 to 5 .

\begin{tabular}{|c|c|c|c|c|c|}
\hline & 1 & 2 & 3 & 4 & 5 \\
\hline Category & $\begin{array}{c}\mathrm{V} \\
\text { Trivial }\end{array}$ & Trivial & Neutral & Importan & $\begin{array}{l}\mathrm{V} \\
\mathrm{Importan} \\
\mathrm{t}\end{array}$ \\
\hline \multicolumn{6}{|l|}{ Products - Excellent quality and service } \\
\hline \multicolumn{6}{|l|}{$\begin{array}{l}\text { Products }- \text { modern \& trendy services that } \\
\text { meets my personal preference and needs }\end{array}$} \\
\hline \multicolumn{6}{|l|}{$\begin{array}{l}\text { Brand image - convey strong upmarket image } \\
\text { and are internationally well known brands }\end{array}$} \\
\hline \multicolumn{6}{|l|}{ Price - attractively priced } \\
\hline \multicolumn{6}{|l|}{$\begin{array}{l}\text { Packaging - attractive, elegant and designed } \\
\text { very comforting }\end{array}$} \\
\hline \multicolumn{6}{|l|}{$\begin{array}{l}\text { Reputation of company - well-known, } \\
\text { established }\end{array}$} \\
\hline \multicolumn{6}{|l|}{$\begin{array}{l}\text { Place }- \text { stores are conveniently located / great } \\
\text { accessibility }\end{array}$} \\
\hline \multicolumn{6}{|l|}{$\begin{array}{l}\text { Promotion - keeping customers informed } \\
\text { through catalogues, monthly newsletter and } \\
\text { advertisements, }\end{array}$} \\
\hline $\begin{array}{l}\text { Customer service }- \text { various modes of } \\
\text { payments, attentive to specific requests, less } \\
\text { waiting time. }\end{array}$ & & & & & \\
\hline
\end{tabular}




\begin{tabular}{|l|l|l|l|l|l||}
\hline $\begin{array}{l}\text { Employees - friendly, knowledgeable, eager to } \\
\text { serve, helpful, proactive \& well-groomed }\end{array}$ & & & & & \\
\hline $\begin{array}{l}\text { Service Experience - warm, relaxing, } \\
\text { satisfying each time I use the service }\end{array}$ & & & & & \\
\hline $\begin{array}{l}\text { Loyalty programme - attractive rewards } \\
\text { programme for loyal customers. }\end{array}$ & & & & & \\
\hline Punctuality - provide on time flight schedule & & & & & \\
\hline
\end{tabular}

4. What media or source did you often use in searching for airline service?

$\square$ Internet
$\square$ Newspaper
$\square$ Television
$\square$ Friends, Family, Relatives Etc.
$\square$ Others

Please circle the appropriate answers for question number five to nine.

5. Does using prestigious and well-known airline made you feel more safe and comfortable?

\begin{tabular}{lllll}
1 & 2 & 3 & 4 & 5 \\
\hline Disagree & & & & Strongly Agree
\end{tabular}

6. Next, do an attractive pricing of airline service attract you?

\begin{tabular}{lllll}
1 & 2 & 3 & 4 & 5 \\
\hline Disagree & & & & Strongly Agree
\end{tabular}

7. Will you come back for the same airline service because of great experience and excellent quality of service?

$\begin{array}{ccccc}1 & 2 & 3 & 4 & 5 \\ \text { Very Unlikely } & & & & \text { Very Likely }\end{array}$

8. Subsequently, does compensation from airline service when unanticipated thing (i.e. Delay flight Schedule, Error check-in etc.) happen is meaningful and essential to you?

$\begin{array}{lllr}1 & 2 & 3 & 4\end{array}$

No Meaning Very meaningful

9. Lastly, if the attributes from question number 5, 6, 7 and 8 are fulfilled and results in satisfaction will you recommend this particular airline service to the others?

Very Unlikely $\quad$ Very Likely

Herewith, I would like to thank you and appreciate for your cooperation. Your feedback is important to the completion and success of this study. 